\title{
The Meth Project and Teen Meth Use New Estimates from the National and State Youth Risk Behavior Surveys
}

\author{
D. Mark Anderson* \\ Department of Agricultural Economics and Economics \\ Montana State University \\ P.O. Box 172920 \\ Bozeman, MT 59717-2920 \\ David Elsea \\ Department of Agricultural and Applied Economics \\ University of Wisconsin - Madison \\ 427 Lorch Street, Taylor Hall \\ Madison, WI 53706-1503
}

\begin{abstract}
Anderson (2010) used data from the Youth Risk Behavior Surveys to estimate the effect of the Montana Meth Project, an anti-methamphetamine advertising campaign, on meth use among high school students. He found little evidence that the campaign actually curbed meth use. In this note, we use data from the national and state Youth Risk Behavior Surveys for the period 1999 through 2011 to build upon the work of Anderson (2010). During this period, a total of eight states adopted anti-meth advertising campaigns. While our results are typically consistent with those of Anderson (2010), we do find some evidence that the Meth Project may have reduced meth use among white high school students.

JEL Codes: H75, I18, K42, M37

Key Words: Meth Project, Methamphetamine Use, Youth Risky Behavior, Anti-Drug Campaign

\footnotetext{
${ }^{*}$ Corresponding author. Email: dwight.anderson@montana.edu. Phone: 406-366-0921. The authors would like to thank Dean Anderson, Daniel Rees, Randy Rucker, Carly Urban, and Mary Beth Walker for comments and suggestions. The authors would also like to thank Lisa Whittle and numerous state YRBS coordinators for their help with obtaining the data used in this paper. The authors have no financial or personal relationships between themselves and others that might bias their work.
} 
"We brought the Meth Project to Georgia to stem the growing methamphetamine epidemic in our state, and we are seeing impressive results."

--Johnny Isakson, Republican Senator of Georgia

\section{INTRODUCTION}

In 2005, Montana adopted an anti-methamphetamine advertising campaign known as the Meth Project. The goal of this campaign is to reduce methamphetamine (meth) use by increasing the perceived risk and decreasing the perceived benefit of trying meth, promoting dialogue about meth between parents and teens, and stigmatizing use (Siebel and Mange 2009). The campaign relies primarily on graphic print impressions, radio and television ads, and highway billboards. The ads consist of disturbing images such as addicts tearing off their own skin, young girls selling their bodies to older men for meth, and meth-crazed teens beating their parents for money. ${ }^{1}$

Due to the apparent success of Montana's campaign, seven additional states have adopted their own Meth Projects (see Table 1). ${ }^{2}$ In 2010, Barron's magazine listed the Meth Project as the third most effective philanthropy in the world (Siebel Scholars 2010). However, after accounting for preexisting downward trends in meth use, Anderson (2010) found little evidence of a relationship between the Montana Meth Project and meth use among high school students. ${ }^{3}$

Because of the focus on Montana, it is unclear whether the results from Anderson (2010) generalize. In an effort to examine whether the Meth Project was more successful elsewhere, we extend the Anderson (2010) analysis through 2011. Similar to Anderson (2010), after

\footnotetext{
${ }^{1}$ To view the Meth Project ads, visit http://montana.methproject.org/Our-Work/view-ads.php.

${ }^{2}$ The editorial board of the Star-Tribune, a major newspaper in Wyoming, was quoted as saying, "...the fact that Wyoming and six other states have launched programs similar to the Montana Meth Project shows plenty of people see it as something worth emulating (Star-Tribune Editorial Board 2010)."

${ }^{3}$ See Anderson (2010) for a detailed description of the Montana Meth Project. See Dobkin and Nicosia (2009) and Cunningham and Finlay (2013) for research on supply-side meth shocks.
} 
accounting for preexisting downward trends in meth use, we find little evidence of a relationship between the Meth Project and meth use within our full sample. However, we do find some evidence that the Meth Project may have decreased meth use among white high school students.

\section{DATA AND EMPIRICAL MODEL}

The data for this study come from the national and state YRBS and cover the period 1999 through 2011. ${ }^{4}$ The national YRBS is conducted biennially by the Centers for Disease Control and Prevention (CDC) and is representative of the population of U.S. high school students. ${ }^{5}$ The state surveys are also school-based and mirror the national surveys in terms of content. Although the state surveys are coordinated by the CDC, they are typically administered by state education and health agencies.

Our analysis uses both of these data sources so that identification comes from as many Meth Project adoptions as possible. While intended to be nationally representative, not all 50 states contribute data to the national YRBS in any given year. ${ }^{6}$ Between 1999 and 2011, 11 states contributed data to the national YRBS every year and six states contributed data before and after the adoption of their Meth Project (Arizona, Colorado, Georgia, Hawaii, Idaho, and Illinois). Appendix Table 1 illustrates the number of observations by year and state in the national YRBS analysis.

\footnotetext{
${ }^{4}$ Anderson (2010) used national YRBS data through 2007 and Montana YRBS data through 2009. It is not possible to observe meth use prior to 1999 because this was the first year the YRBS asked respondents about meth use.

${ }^{5}$ Federal agencies use the national YRBS data to follow trends in adolescent behaviors such as eating and exercise habits, violence, sexuality, and substance use. These data have also been used by researchers to evaluate the impacts of state-level policies. For examples, see Tremblay and Ling (2005), Carpenter and Cook (2008), Carpenter and Stehr (2008), Cawley et al. (2007), and Anderson (2014).

${ }^{6}$ In order to link respondents to their state of residence, we obtained the restricted-use versions of the national YRBS.
} 
Most states conducted their own version of the YRBS at some point between 1999 and 2011. We have obtained data from 45 states, seven of which conducted surveys before and after the adoption of their Meth Project (Arizona, Colorado, Georgia, Idaho, Illinois, Montana, and Wyoming). ${ }^{7}$ Appendix Table 2 illustrates the number of observations each state contributed to the state YRBS analysis. In combination, the national and state YRBS data cover all states and the District of Columbia. All eight states with Meth Projects contributed data before and after the adoption of their anti-meth campaign. ${ }^{8}$ Table 2 provides descriptive statistics for the national and state YRBS samples. Means are reported by whether a Meth Project was present in the respondent's state of residence during the year of the interview. On average, Meth Project states have lower rates of meth use, a lower percentage of black students enrolled in their high schools, and higher unemployment rates.

Figure 1 presents trends in meth use based on the combined national and state YRBS data. It is apparent that meth use has been trending smoothly downward in all states during the period under study. If the Meth Project had an effect, then we would expect to see an acceleration of this trend as states began adopting the campaign. Figure 1 provides no evidence to support this hypothesis. If anything, the decrease in meth use appears to have slowed among adopting states after 2005, the inaugural year of the Meth Project in Montana.

To examine the relationship between the Meth Project and meth use among youths in a more rigorous fashion, we exploit the temporal and spatial variation in the adoption of these

\footnotetext{
${ }^{7}$ Roughly half of these states have given the CDC permission to release their data. To obtain the remaining data, direct requests were made to each state.

${ }^{8}$ In the combined national and state YRBS sample, we have full coverage for 5 of the 8 Meth Project states. Idaho did not participate in the national or state YRBS in 1999 and Colorado did not participate in the national or state YRBS in 1999, 2003, and 2007. In addition, we only have data on Hawaii for 1999 and 2009 from the national YRBS. Hawaii conducted a state YRBS in 1999, 2005, 2007, 2009, and 2011. Unfortunately, our attempts at obtaining these data were rebuffed.
} 
campaigns and estimate a standard difference-in-differences model. Specifically, our estimating equation is:

$$
\text { Meth use }_{i s t}=\beta_{0}+\beta_{1} \text { Meth } \text { Project }_{s t}+\boldsymbol{X}_{i s t} \boldsymbol{\beta}_{2}+v_{s}+w_{t}+\Theta_{s} \cdot t+\varepsilon_{i s t}
$$

where $i$ indexes individuals, $s$ indexes states, and $t$ indexes years. The dependent variable, Meth $u_{s e} e_{i s t}$, is equal to 1 if respondent $i$ reported having ever used meth, and is equal to 0 otherwise. The vector $\boldsymbol{X}_{\text {ist }}$ includes individual-level controls for age, sex, race and grade, and the unemployment rate in respondent $i$ 's state. ${ }^{9}$ The vectors $v_{s}$ and $w_{t}$ represent state and year fixed effects, respectively, and state-specific linear time trends are represented by $\Theta_{s} \bullet t$. The variable of interest, Meth Project st $_{\text {, }}$ is an indicator for whether a Meth Project had been implemented by state $s$ by year $t .^{10}$ All regressions are estimated as linear probability models and standard errors are corrected for clustering at the state level (Bertrand et al. 2004). ${ }^{11}$

\section{RESULTS}

Table 3 presents estimates of equation (1) for the national, state, and combined YRBS samples. For each sample, results from specifications with and without state-specific linear time trends are presented. Figure 1 clearly illustrates the importance of controlling for preexisting trends in meth use.

\footnotetext{
${ }^{9}$ The regressions based on the combined YRBS sample also include a dummy variable that indicates whether the respondent was sampled in the national YRBS or the state YRBS.

${ }^{10}$ This variable takes on fractional values during the year in which a Meth Project was adopted.

${ }^{11}$ Logit and probit models yielded similar results.
} 
Using the state YRBS data and a specification without state-specific linear time trends, the adoption of a Meth Project is associated with a 1.53 percentage point decrease in the probability of meth use. The same specification yields a similar estimate using the combined YRBS data. ${ }^{12}$ However, when state-specific linear time trends are included, these estimates become much smaller in magnitude and lose statistical significance. ${ }^{13}$

The state-specific linear time trends are included to avoid confounding the treatment effect with pre-treatment trends. However, when there are insufficient observations in the pretreatment period, empirically disentangling the trends and the treatment effect becomes difficult (Wolfers 2006). To address this issue, we consider a series of sensitivity analyses in Table 4. Here, we restrict focus to treatment states with relatively more pre-treatment years of data. For example, in panel A of Table 4, we drop treated states with only one year of pre-Meth Project data; in panel $\mathrm{C}$, we drop treated states with three or fewer years of pre-Meth Project data. In general, these results support the findings from Table $3 .{ }^{14}$

In Table 5, we consider whether the relationship between the Meth Project depends on age, gender, or race. ${ }^{15}$ All estimates presented are based on specifications that include state-

\footnotetext{
${ }^{12}$ We also experimented with using the wild cluster bootstrap method suggested by Cameron et al. (2008) to produce $\mathrm{t}$-statistics. Wild cluster bootstrap critical values provide an asymptotic refinement and may work better than other inference methods for OLS when the number of clusters is small. Both of the statistically significant effects shown in Table 3 became statistically insignificant at conventional levels when using the wild cluster bootstrap procedure.

${ }^{13}$ For the national YRBS analysis, we considered weighted regressions using the sample weights provided by the CDC. These results were similar to those reported in Table 3. Because the national and state YRBS data were not specifically designed to be pooled, we also experimented with including the interaction term, Meth Project*National $Y R B S$, on the right-hand-side of the estimating equation, where National YRBS is equal to one if the respondent was part of the national YRBS sample and equal to zero if the respondent was part of the state YRBS sample. This interaction term was never statistically distinguishable from zero, quelling some concerns about the viability of combining the two data sets.

${ }^{14}$ It is also important to note that the national YRBS data set represents a highly unbalanced panel. We experimented with running our national YRBS analyses on a sample where only states with one or fewer missing years of data were included. These results were very similar to those shown in Table 3.

${ }^{15}$ Appendix Table 3 shows mean rates of meth use by age, gender, and race.
} 
specific linear time trends. The results in panel A compare estimates for YRBS respondents who were under the age of 17 at the time of the interview with estimates for respondents who were 17 years of age or older. For both groups, the relationship between the Meth Project and meth use is consistently statistically insignificant.

Panel B of Table 5 provides estimates by gender. The relationship between the Meth Project and meth use among males is negative and statistically significant when based on the national YRBS data. In the state and combined samples, however, this relationship becomes statistically indistinguishable from zero. ${ }^{16}$ There is no evidence that the Meth Project had an effect on female meth use.

Finally, the results in panel $\mathrm{C}$ of Table 5 provide estimates by race (i.e., white vs. nonwhite). The relationship between the Meth Project and meth use among white high school students is negative and statistically significant in the state YRBS sample. ${ }^{17}$ While this relationship becomes statistically insignificant in the combined sample, this may simply be due to the relatively small number of observations contributed by the treated states in the national YRBS data. Consequently, we leave open the possibility that the Meth Project had an effect on white students. There is no evidence that the Meth Project had an effect on meth use among non-white students. ${ }^{18}$

\footnotetext{
${ }^{16}$ The statistically significant effect for males in the national YRBS sample became statistically insignificant when using the wild cluster bootstrap procedure described by Cameron et al. (2008). It is important to note that the coefficient estimates for males across the national and state YRBS samples are statistically indistinguishable from one another.

${ }^{17}$ The statistically significant effect for whites in the state YRBS sample became statistically insignificant when using the wild cluster bootstrap procedure described by Cameron et al. (2008). It is important to note that the coefficient estimates for whites across the national and state YRBS samples are statistically indistinguishable from one another.

${ }^{18}$ To further address issues with combining the national and state YRBS data sets, we collected population data from the National Cancer Institute's Surveillance Epidemiology and End Results Program (http://seer.cancer.gov/popdata/). We used these data to assign population weights to each respondent based on state of residence, age, gender, and race. The idea of weighting using these data is to better ensure representation at the
} 


\section{CONCLUSION}

The Meth Project, an anti-methamphetamine advertising campaign, is intended to discourage meth use among young people. Since Montana established the first campaign in 2005, seven other states have adopted their own Meth Projects. Using data from the YRBS, Anderson (2010) found no evidence of a relationship between the Montana Meth Project and meth use among high school students.

We build upon the work of Anderson (2010) by using data from the national and state YRBS for the period 1999 through 2011 to examine the relationship between the Meth Project and meth use. During this period, eight states adopted anti-meth campaigns. While our results are typically consistent with those of Anderson (2010), we do find some evidence that the Meth Project may have reduced meth use among white high school students.

\section{REFERENCES}

Anderson, D. Mark. 2010. "Does Information Matter? The Effect of the Meth Project on Meth Use among Youths." Journal of Health Economics 29: $732-742$.

Anderson, D. Mark. 2014. "In School and Out of Trouble? The Minimum Dropout Age and Juvenile Crime." Review of Economics and Statistics 96.

Bertrand, Marianne, Esther Duflo, and Sendhil Mullainathan. 2004. "How Much Should We Trust Differences-in-Differences Estimates?" Quarterly Journal of Economics119: 249276.

Cameron, A. Colin, Jonah B. Gelbach, and Douglas L. Miller. 2008. "Bootstrap-Based Improvements for Inference with Clustered Errors." Review of Economics and Statistics 90: 414-427.

national level when estimating regressions based on the pooled national and state YRBS samples. The results based on this exercise support the finding that the Meth Project has not decreased meth use among teens (see Appendix Table 4). 
Carpenter, Christopher and Philip Cook. 2008. "Cigarette Taxes and Youth Smoking: New Evidence from National, State, and Local Youth Risk Behavior Surveys." Journal of Health Economics 27: 287-299.

Carpenter, Christopher and Mark Stehr. 2008. "The Effects of Mandatory Seatbelt Laws on Seatbelt Use, Motor Vehicle Fatalities, and Crash-Related Injuries among Youths." Journal of Health Economics 27: 642-662.

Cawley, John, Chad Meyerhoefer, and David Newhouse. "The Impact of State Physical Education Requirements on Youth Physical Activity and Overweight." Health Economics 16: $1287-1301$.

Cunningham, Scott and Keith Finlay. 2013. "Parental Substance Use and Foster Care: Evidence from Two Methamphetamine Supply Shocks." Economic Inquiry 51: 764-782.

Dobkin, Carlos and Nancy Nicosia. 2009. "The War on Drugs: Methamphetamine, Public Health, and Crime." American Economic Review 99: 324-349.

Siebel Scholars. 2010. "Meth Project Named Third Most Effective Philanthropy in the World by Barron's Magazine." Available at: http://www.siebelscholars.com/news/meth-project-named-third-most-effectivephilanthropy-world-barrons-magazine.

Siebel, Thomas and Steven Mange. 2009. "The Montana Meth Project: 'Unselling' a Dangerous Drug." Stanford Law and Policy Review 20: 405-416.

Star-Tribune Editorial Board. 2010. "Wyoming Meth Project is Making a Difference." StarTribune. Available at: http://trib.com/news/opinion/editorial/wyoming-meth-project-is-making-adifference/article_ce543000-c3fb-5e4b-9934-7a0e69813b8f.html.

Tremblay, Carol and Davina Ling. 2005. "AIDS Education, Condom Demand, and the Sexual Activity of American Youth." Health Economics 14: 851-867.

Wolfers, Justin. 2006. "Did Unilateral Divorce Raise Divorce Rates? A Reconciliation and New Results." American Economic Review 96: 1802-1820. 


\section{Figure 1}

\section{Fraction Reporting Meth Use}

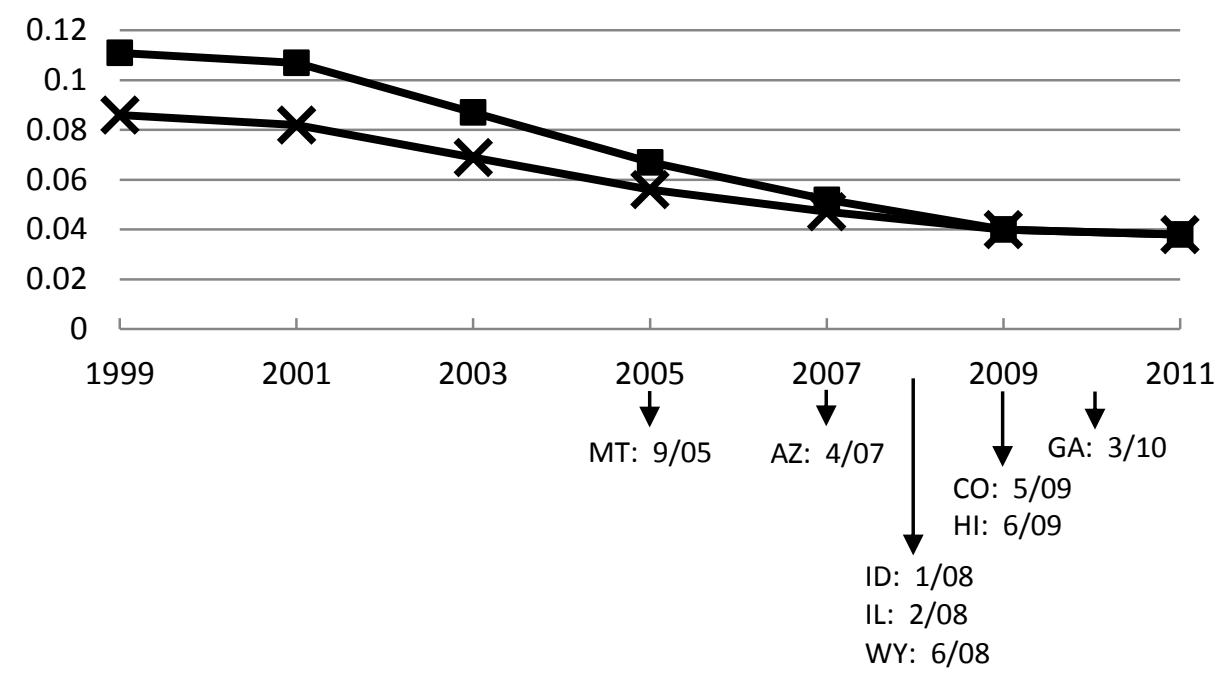

-States that adopted a Meth Project $\sim$ States without a Meth Project 
Table 1. Meth Projects, 1999-2011

\begin{tabular}{ll}
\hline & Effective Date \\
\hline Arizona & April 2007 \\
Colorado & May 2009 \\
Georgia & March 2010 \\
Hawaii & June 2009 \\
Idaho & January 2008 \\
Illinois & February 2008 \\
Montana & September 2005 \\
Wyoming & June 2008 \\
\hline
\end{tabular}




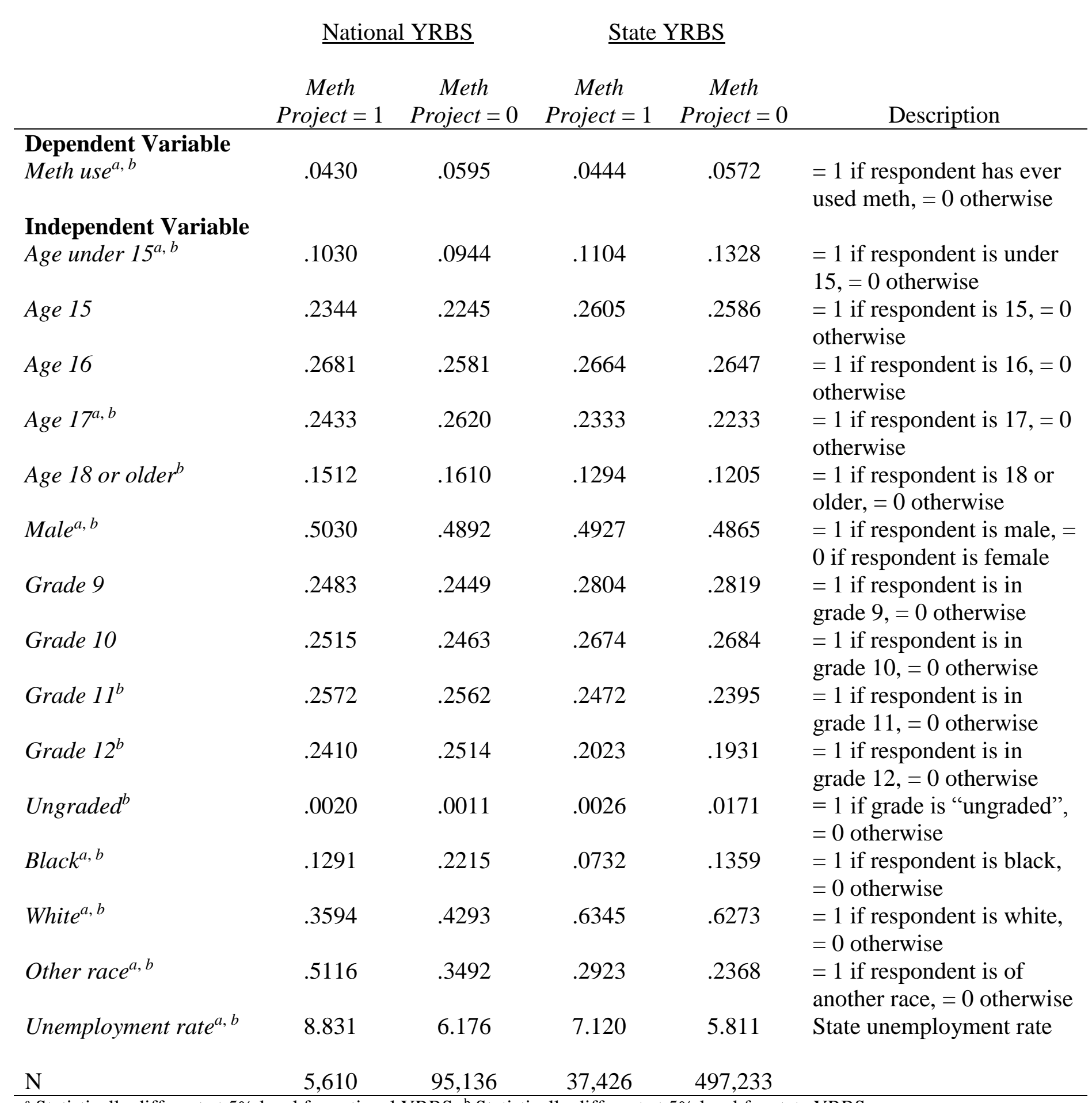

\footnotetext{
${ }^{\mathrm{a}}$ Statistically different at 5\% level for national YRBS; ${ }^{\mathrm{b}}$ Statistically different at 5\% level for state YRBS.
}

Notes: Means are based on unweighted data from the national and state YRBS 
Table 3. Meth Projects and Youth Meth Use

\section{$\underline{\text { National YRBS }}$}

Meth Project

$\mathrm{N}$

Covariates

State FEs

Year FEs

State-specific trends $\underline{\text { Combined National and State }}$

\section{$\underline{\text { State YRBS }}$}

$\begin{array}{cc}-.0153 * * & -.0050 \\ (.0074) & (.0064)\end{array}$

$534,659 \quad 534,659$

635,405

Notes: Each cell represents a separate OLS estimate based on data from the YRBS (1999-2011); the covariates are listed in Table 2. The combined national and state YRBS regressions include a dummy variable indicating whether the respondent was sampled in the national YRBS or the state YRBS. Standard errors, corrected for clustering at the state level, are in parentheses. 
Table 4. Sensitivity of Results to Sample Selection

Panel A: Drop treated states with only one year of pre-

Meth Project data

Meth Project

$\mathrm{N}$

Treated states in sample

Panel B: Drop treated states with two or fewer years of pre-Meth Project data

Meth Project

$\mathrm{N}$

Treated states in sample

Panel C: Drop treated states with three or fewer years of pre-Meth Project data

Meth Project

$\mathrm{N}$

Treated states in sample

Covariates

State FEs

Year FEs

State-specific trends

National YRBS

$\begin{array}{ll}-.0123 & -.0086 \\ (.0212) & (.0081)\end{array}$

98,927

98,927

AZ, GA, ID, IL
$-.0066$

(.0074)

98,271

98,271

AZ, GA, IL

State YRBS

$\begin{array}{cc}-.0192 * * & -.0072 \\ (.0082) & (.0065)\end{array}$

$514,752 \quad 514,752$

GA, ID, MT, WY

$\begin{array}{cc}-.0192 * * & -.0072 \\ (.0082) & (.0065)\end{array}$

$514,752 \quad 514,752$

GA, ID, MT, WY

$\begin{array}{ll}-.0112 & -.0066 \\ (.0225) & (.0074) \\ 98,271 & 98,271\end{array}$

$-.0089$

(.0060)

$-.0047$

(.0080)

494, 124

494, 124

GA, ID, WY

AZ, GA, IL

Yes $\quad$ Yes

Yes $\quad$ Yes

Yes Yes

$\begin{array}{ll}\text { Yes } & \text { Yes } \\ \text { Yes } & \text { Yes } \\ \text { Yes } & \text { Yes }\end{array}$

Yes

No

Yes

Combined National and State

$\begin{array}{cc}-.0161 * & -.0016 \\ (.0083) & (.0059) \\ 634,863 & 634,863\end{array}$

AZ, CO, GA, ID, IL, MT, WY

* Statistically significant at $10 \%$ level; ** at $5 \%$ level; *** at $1 \%$ level.

Notes: Each cell represents a separate OLS estimate based on data from the YRBS (1999-2011); the covariates are listed in Table 2. The combined national and state YRBS regressions include a dummy variable indicating whether the respondent was sampled in the national YRBS or the state YRBS. Standard errors, corrected for clustering at the state level, are in parentheses. 
Table 5. Meth Projects and Youth Meth Use by Age, Gender, and Race

Panel A: Meth Use by Age

$\underline{\text { National YRBS }}$

$\underline{\text { State YRBS }}$

Combined National and State

Meth Project

\begin{tabular}{cccccc} 
Age $<17$ & Age $\geq 17$ & Age $<17$ & Age $\geq 17$ & Age $<17$ & Age $\geq 17$ \\
\hline-.0008 & -.0058 & -.0056 & -.0045 & -.0032 & -.0015 \\
$(.0069)$ & $(.0155)$ & $(.0048)$ & $(.0093)$ & $(.0042)$ & $(.0085)$
\end{tabular}

$\mathrm{N}$

58,29

42,455

350,122

184,537

408,413

226,992

Panel B: Meth Use by Gender

Meth Project

\begin{tabular}{cccccc} 
Male & Female & Male & Female & Male & Female \\
\hline$-.0129 * *$ & .0066 & -.0039 & -.0065 & -.0003 & -.0032 \\
$(.0063)$ & $(.0143)$ & $(.0063)$ & $(.0072)$ & $(.0060)$ & $(.0068)$
\end{tabular}

$\mathrm{N}$

$49,366 \quad 51,380$

260,351

274,308

309,717

325,688

Panel C: Meth Use by Race

Meth Project

\begin{tabular}{cccccc} 
White & Non-white & White & Non-white & White & Non-white \\
\hline-.0023 & -.0012 & $-.0089^{* *}$ & .0040 & -.0065 & .0071 \\
$(.0122)$ & $(.0145)$ & $(.0041)$ & $(.0099)$ & $(.0047)$ & $(.0078)$
\end{tabular}

$\mathrm{N}$

$42,855 \quad 57,891$

335,649

199,010

378,504

256,901

Covariates

Yes $\quad$ Yes

State FEs

Yes

Yes

Yes

Yes

Yes

Yes

Yes

Yes

State-specific trends

Yes

Yes

Yes

Yes

Yes

Yes

$\begin{array}{ll}\text { Yes } & \text { Yes } \\ \text { Yes } & \text { Yes } \\ \text { Yes } & \text { Yes } \\ \text { Yes } & \text { Yes }\end{array}$

* Statistically significant at $10 \%$ level; $* *$ at $5 \%$ level; *** at $1 \%$ level.

Notes: Each cell represents a separate OLS estimate based on data from the YRBS (1999-2011); the covariates are listed in Table 2. The combined national and state YRBS regressions include a dummy variable indicating whether the respondent was sampled in the national YRBS or the state YRBS. Standard errors, corrected for clustering at the state level, are in parentheses. 
Appendix Table 1. Number of Observations by State-Year: National YRBS

\begin{tabular}{|c|c|c|c|c|c|c|c|c|}
\hline & 1999 & 2001 & 2003 & 2005 & 2007 & 2009 & 2011 & Total \\
\hline Alabama & 59 & 310 & 647 & $\ldots$ & 481 & 1,055 & 314 & 2,866 \\
\hline Arizona* & 131 & 408 & 344 & 281 & 599 & 358 & 1,117 & 3,238 \\
\hline Arkansas & $\ldots$ & $\ldots$ & 266 & $\ldots$ & 416 & 298 & $\ldots$ & 980 \\
\hline California & 2,479 & 2,184 & 1,723 & 1,545 & 2,099 & 2,789 & 1,858 & 14,677 \\
\hline Colorado* & $\ldots$ & 655 & $\ldots$ & $\ldots$ & $\ldots$ & 193 & 245 & 1,093 \\
\hline Connecticut & $\ldots$ & $\ldots$ & $\ldots$ & 233 & $\ldots$ & $\ldots$ & $\ldots$ & 233 \\
\hline Delaware & $\ldots$ & $\ldots$ & 364 & $\ldots$ & $\ldots$ & $\ldots$ & 225 & 589 \\
\hline D.C. & $\ldots$ & $\ldots$ & $\ldots$ & $\ldots$ & $\ldots$ & $\ldots$ & 306 & 306 \\
\hline Florida & 860 & 1,060 & 1,498 & 535 & 740 & 225 & 1,145 & 6,063 \\
\hline Georgia* & 810 & 486 & 420 & 1,833 & 347 & 1,315 & 125 & 5,336 \\
\hline Hawaii* & 308 & $\ldots$ & $\ldots$ & $\ldots$ & $\ldots$ & 234 & $\ldots$ & 542 \\
\hline Idaho* & $\ldots$ & 156 & $\ldots$ & 240 & $\ldots$ & $\ldots$ & 260 & 656 \\
\hline Illinois* & 228 & 438 & 316 & 490 & 585 & 1,489 & 990 & 4,536 \\
\hline Indiana & $\ldots$ & 177 & 417 & 170 & 400 & $\ldots$ & 270 & 1,434 \\
\hline Iowa & $\ldots$ & $\ldots$ & $\ldots$ & 238 & 246 & $\ldots$ & $\ldots$ & 484 \\
\hline Kansas & $\ldots$ & $\ldots$ & 328 & 277 & $\ldots$ & 199 & 301 & 1,105 \\
\hline Kentucky & $\ldots$ & $\ldots$ & $\ldots$ & 531 & 359 & $\ldots$ & 214 & 1,104 \\
\hline Louisiana & 621 & $\ldots$ & 688 & 157 & $\ldots$ & 427 & $\ldots$ & 1,893 \\
\hline Maine & 197 & 203 & 196 & $\ldots$ & $\ldots$ & $\ldots$ & $\ldots$ & 596 \\
\hline Maryland & $\ldots$ & $\ldots$ & 259 & $\ldots$ & $\ldots$ & $\ldots$ & $\ldots$ & 259 \\
\hline Massachusetts & $\ldots$ & 253 & 212 & 256 & 711 & $\ldots$ & 289 & 1,721 \\
\hline Michigan & 522 & 338 & 398 & 295 & 297 & 320 & 625 & 2,795 \\
\hline Minnesota & $\ldots$ & $\ldots$ & $\ldots$ & 95 & $\ldots$ & 188 & $\ldots$ & 283 \\
\hline Mississippi & 637 & 339 & $\ldots$ & $\ldots$ & 359 & $\ldots$ & 94 & 1,429 \\
\hline Missouri & 554 & 463 & 264 & 102 & 345 & 84 & 343 & 2,155 \\
\hline Montana* & $\cdots$ & 184 & $\cdots$ & $\ldots$ & $\ldots$ & $\cdots$ & $\ldots$ & 184 \\
\hline Nevada & $\ldots$ & 236 & $\ldots$ & $\ldots$ & $\ldots$ & 386 & 207 & 829 \\
\hline New Jersey & 235 & 219 & 305 & 313 & 686 & 479 & 113 & 2,350 \\
\hline New Mexico & $\ldots$ & 155 & 104 & $\ldots$ & 220 & 601 & $\ldots$ & 1,080 \\
\hline New York & 726 & 308 & 910 & 461 & 909 & 1,191 & 643 & 5,148 \\
\hline North Carolina & 509 & 666 & $\ldots$ & 644 & 580 & $\ldots$ & 1,103 & 3,502 \\
\hline Ohio & 561 & 224 & 297 & 277 & $\ldots$ & $\ldots$ & $\ldots$ & 1,359 \\
\hline Oklahoma & $\ldots$ & 395 & $\ldots$ & 235 & 280 & $\ldots$ & $\ldots$ & 910 \\
\hline Oregon & $\ldots$ & 184 & $\ldots$ & 268 & $\ldots$ & 246 & $\ldots$ & 698 \\
\hline Pennsylvania & 485 & $\ldots$ & 316 & 418 & 210 & 1,050 & 434 & 2,913 \\
\hline Rhode Island & 75 & $\ldots$ & $\ldots$ & $\ldots$ & $\cdots$ & $\cdots$ & $\cdots$ & 75 \\
\hline South Carolina & 798 & $\ldots$ & 884 & 285 & $\ldots$ & $\ldots$ & $\ldots$ & 1,967 \\
\hline South Dakota & $\ldots$ & $\ldots$ & 297 & $\ldots$ & $\ldots$ & $\ldots$ & $\ldots$ & 297 \\
\hline Tennessee & 265 & 607 & $\ldots$ & 394 & 163 & $\ldots$ & 290 & 1,719 \\
\hline Texas & 2,707 & 2,042 & 2,617 & 1,717 & 1,463 & 1,321 & 1,775 & 13,642 \\
\hline Utah & $\cdots$ & $\cdots$ & 178 & 273 & 197 & $\cdots$ & $\cdots$ & 648 \\
\hline Vermont & $\ldots$ & $\ldots$ & 256 & $\ldots$ & $\ldots$ & $\ldots$ & $\ldots$ & 256 \\
\hline
\end{tabular}


Appendix Table 1. Number of Observations by State-Year: National YRBS

\begin{tabular}{lcccccccc}
\hline & 1999 & 2001 & 2003 & 2005 & 2007 & 2009 & 2011 & Total \\
\hline Virginia & 742 & $\ldots$ & 243 & 348 & 436 & 98 & 202 & 2,069 \\
Washington & $\ldots$ & 52 & $\ldots$ & 101 & $\ldots$ & 245 & 167 & 565 \\
West Virginia & $\ldots$ & 262 & $\ldots$ & 230 & 244 & 465 & 257 & 1,458 \\
Wisconsin & 536 & 235 & 178 & 241 & 178 & 682 & 654 & 2,704 \\
\hline
\end{tabular}

Notes: States that adopted a Meth Project are denoted with a star superscript and post-adoption observations are italicized. 
Appendix Table 2. Number of Observations by State-Year: State YRBS

\begin{tabular}{|c|c|c|c|c|c|c|c|c|}
\hline & 1999 & 2001 & 2003 & 2005 & 2007 & 2009 & 2011 & Total \\
\hline Alabama & 2,038 & 1,537 & 1,063 & 1,075 & $\ldots$ & 1,442 & 1,322 & 8,477 \\
\hline Alaska & $\ldots$ & $\ldots$ & 1,445 & $\ldots$ & 1,265 & 1,213 & 1,259 & 5,182 \\
\hline Arizona* & $\ldots$ & $\ldots$ & $\ldots$ & 1,904 & 1,655 & 1,483 & 1,899 & 6,941 \\
\hline Arkansas & 1,457 & 1,670 & $\ldots$ & 1,505 & 1,540 & 1,596 & 1,310 & 9,078 \\
\hline Colorado* & $\ldots$ & $\ldots$ & $\ldots$ & 1,464 & $\ldots$ & 1,445 & 1,404 & 4,313 \\
\hline Connecticut & $\ldots$ & $\ldots$ & $\ldots$ & 2,167 & 1,980 & 2,304 & 1,977 & 8,428 \\
\hline Delaware & 2,317 & 2,844 & 2,950 & 2,607 & 2,344 & 2,220 & 2,152 & 17,434 \\
\hline Florida & $\ldots$ & 4,109 & 3,952 & 4,412 & $\ldots$ & $\ldots$ & $\ldots$ & 12,473 \\
\hline Georgia* & $\ldots$ & $\ldots$ & 2,045 & 1,698 & 2,371 & 1,812 & 1,777 & 9,703 \\
\hline Idaho* & $\ldots$ & 1,684 & 1,698 & 1,429 & 1,378 & 2,094 & 1,648 & 9,931 \\
\hline Illinois* & $\ldots$ & $\ldots$ & $\ldots$ & $\ldots$ & 2,311 & 2,926 & 3,416 & 8,653 \\
\hline Indiana & $\ldots$ & $\ldots$ & 1,631 & 1,508 & 2,248 & 1,467 & 2,726 & 9,580 \\
\hline Iowa & $\ldots$ & $\ldots$ & $\ldots$ & 1,351 & 1,418 & $\ldots$ & 1,511 & 4,280 \\
\hline Kansas & $\ldots$ & $\ldots$ & $\ldots$ & 1,636 & 1,685 & 1,982 & 1,811 & 7,114 \\
\hline Kentucky & $\ldots$ & $\ldots$ & 1,574 & $\ldots$ & 3,428 & 1,723 & 1,650 & 8,375 \\
\hline Louisiana & $\ldots$ & $\ldots$ & $\ldots$ & $\ldots$ & $\ldots$ & 984 & 1,107 & 2,091 \\
\hline Maine & $\ldots$ & 1,308 & 1,626 & 1,326 & 1,259 & $\ldots$ & $\ldots$ & 5,519 \\
\hline Maryland & $\ldots$ & $\ldots$ & $\ldots$ & 1,382 & 1,479 & 1,579 & 2,718 & 7,158 \\
\hline Massachusetts & $\ldots$ & $\ldots$ & 3,528 & 3,301 & 3,020 & 2,608 & 2,623 & 15,080 \\
\hline Michigan & 2,602 & 3,501 & 3,376 & 3,195 & 3,414 & 3,281 & 4,083 & 23,452 \\
\hline Mississippi & 1,594 & 1,783 & 1,465 & $\ldots$ & 1,553 & 1,751 & 1,792 & 9,938 \\
\hline Missouri & 1,613 & 1,631 & 1,530 & 1,857 & 1,515 & 1,592 & $\ldots$ & 9,738 \\
\hline Montana* & 2,881 & 2,582 & 2,669 & 2,906 & 3,831 & 1,773 & 3,986 & 20,628 \\
\hline Nebraska & $\ldots$ & $\ldots$ & 2,869 & 3,681 & $\ldots$ & $\ldots$ & $\ldots$ & 6,550 \\
\hline Nevada & 1,669 & 1,428 & 1,942 & 1,518 & 1,714 & 2,019 & $\ldots$ & 10,290 \\
\hline New Hampshire & $\ldots$ & $\ldots$ & 1,312 & 1,249 & 1,577 & 1,453 & 1,358 & 6,949 \\
\hline New Jersey & $\ldots$ & 2,028 & $\ldots$ & 1,480 & $\ldots$ & 1,694 & 1,617 & 6,819 \\
\hline New Mexico & $\ldots$ & $\ldots$ & $\ldots$ & $\ldots$ & 2,523 & 4,849 & 5,638 & 13,010 \\
\hline New York & 3,314 & $\ldots$ & 9,004 & 9,225 & 12,564 & 13,625 & 12,300 & 60,032 \\
\hline North Carolina & $\ldots$ & 2,517 & 2,518 & 3,804 & 3,389 & 5,530 & 2,205 & 19,963 \\
\hline North Dakota & 1,790 & 1,573 & 1,642 & 1,711 & 1,689 & 1,783 & $\ldots$ & 10,188 \\
\hline Ohio & 2,021 & $\ldots$ & 1,183 & 1,372 & 2,419 & $\ldots$ & $\ldots$ & 6,995 \\
\hline Oklahoma & $\ldots$ & $\ldots$ & 1,366 & 1,686 & 2,561 & 1,386 & 1,133 & 8,132 \\
\hline Pennsylvania & $\ldots$ & $\ldots$ & $\ldots$ & $\ldots$ & $\ldots$ & 2,025 & $\ldots$ & 2,025 \\
\hline Rhode Island & $\ldots$ & 1,361 & 1,776 & 2,303 & $\ldots$ & $\ldots$ & $\ldots$ & 5,440 \\
\hline South Carolina & 4,552 & $\ldots$ & $\ldots$ & 1,265 & 1,204 & 1,054 & 1,404 & 9,479 \\
\hline South Dakota & 1,645 & 1,591 & 1,795 & 1,557 & 1,572 & 2,115 & 1,499 & 11,774 \\
\hline Tennessee & $\ldots$ & $\ldots$ & 1,919 & 1,525 & 2,017 & 2,166 & 2,574 & 10,201 \\
\hline Texas & $\ldots$ & 6,933 & $\ldots$ & 4,088 & 3,106 & 3,427 & 4,009 & 21,563 \\
\hline Utah & 1,477 & 1,043 & 1,418 & 1,518 & 1,910 & 1,541 & 1,652 & 10,559 \\
\hline Vermont & $\ldots$ & 9,012 & 7,903 & 9,072 & 7,309 & 9,928 & 8,240 & 51,464 \\
\hline
\end{tabular}




\section{Appendix Table 2. Number of Observations by State-Year: State YRBS}

\begin{tabular}{lcccccccc}
\hline & 1999 & 2001 & 2003 & 2005 & 2007 & 2009 & 2011 & Total \\
\hline Virginia & $\ldots$ & $\ldots$ & $\ldots$ & $\ldots$ & $\ldots$ & $\ldots$ & 1,360 & 1,360 \\
West Virginia & 1,467 & $\ldots$ & 1,724 & 1,348 & 1,351 & 1,553 & 2,112 & 9,555 \\
Wisconsin & 1,314 & 2,088 & $\ldots$ & 2,345 & 2,046 & 2,386 & 2,949 & 13,128 \\
Wyoming* & 1,624 & 2,712 & 1,516 & 2,440 & 2,142 & 2,794 & 2,389 & 15,617 \\
\hline
\end{tabular}

Notes: States that adopted a Meth Project are denoted with a star superscript and postadoption observations are italicized. 
Appendix Table 3. Descriptive Statistics for Meth Use by Age, Gender, and Race

National YRBS

$\underline{\text { State YRBS }}$

Panel A: Meth Use by Age

Meth use $^{\mathrm{a}, \mathrm{b}}$

\begin{tabular}{cccc} 
Age $<17$ & Age $\geq 17$ & Age $<17$ & Age $\geq 17$ \\
\hline .0536 & .0655 & .0502 & .0679
\end{tabular}

Panel B: Meth Use by Gender

Meth use $e^{\mathrm{a}, \mathrm{b}}$

\begin{tabular}{cccc} 
Male & Female & Male & Female \\
\hline .0658 & .0517 & .0640 & .0490
\end{tabular}

Panel C: Meth Use by Race

Meth use

\begin{tabular}{cccc} 
White & Non-white & White & Non-white \\
\hline .0687 & .0511 & .0562 & .0565
\end{tabular}

${ }^{\mathrm{a}}$ Statistically different at 5\% level for national YRBS; ${ }^{\mathrm{b}}$ Statistically different at 5\% level for state YRBS.

Notes: Means are based on unweighted data from the national and state YRBS. 


\section{Appendix Table 4. Population Weighted Analysis for the Combined National and State YRBS}

\section{Panel A: Full Sample}

Meth Project

\begin{tabular}{cc}
\multicolumn{2}{c}{ Full Sample } \\
\hline-.0030 & -.0007 \\
$(.0061)$ & $(.0053)$ \\
635,405 & 635,405 \\
No & Yes
\end{tabular}

State-specific trends

Panel B: Meth Use by Age

Meth Project

\begin{tabular}{cc} 
Age $<17$ & Age $\geq 17$ \\
\hline-.0066 & .0063 \\
$(.0064)$ & $(.0055)$ \\
& \\
408,413 & 226,992
\end{tabular}

State-specific trends

Yes Yes

Panel C: Meth Use by Gender

Meth Project

\begin{tabular}{cc} 
Male & Female \\
\hline-.0070 & .0056 \\
$(.0103)$ & $(.0061)$ \\
& \\
309,717 & 325,688
\end{tabular}

State-specific trends

Yes

Yes

Panel D: Meth Use by Race

Meth Project

\begin{tabular}{cc} 
White & Non-white \\
\hline-.0028 & $.0107 * * *$ \\
$(.0057)$ & $(.0037)$ \\
& \\
378,504 & 256,901
\end{tabular}

State-specific trends

Yes

Yes

* Statistically significant at $10 \%$ level; ** at $5 \%$ level; *** at $1 \%$ level.

Notes: Each cell represents a separate OLS estimate based on data from the YRBS (1999-2011). All models control for the covariates listed in Table 2, a dummy variable indicating whether the respondent was sampled in the national YRBS or the state YRBS, year fixed effects, and state fixed effects. Standard errors, corrected for clustering at the state level, are in parentheses. 